\title{
Sero Status and Presumed Risk Factors Assessment for Bovine Herpesvirus-1 in North Western, Ethiopia
}

\section{Zewde $\mathrm{D}^{1 *}$, Tadesse $\mathrm{T}^{2}$ and Alemu $\mathrm{S}^{2}$}

${ }^{1}$ National Animal Health Diagnostic and Investigation Center, Sebeta, Ethiopia

${ }^{2}$ Haramaya University College of Veterinary Medicine, Dire Dawa, Ethiopia

*Corresponding author: Demeke Zewde, National Animal Health Diagnostic and Investigation Center, POBox: 04, Sebeta, Ethiopia

Received: July 05, 2021; Accepted: July 31, 2021; Published: August 07, 2021

\begin{abstract}
A cross sectional study was conducted from November 2020 to June 2021 on a total of 442 randomly selected indigenous zebus (bos indicus) of extensively and semi-intensively managed cattle's. These cattle's were sampled from East Gojam $(n=137)$, west Gojam $(n=160)$ and Awi zone $(n=145)$ north western part of Ethiopia. Indirect Enzyme-Linked Immune-Sorbent Assay (I-ELISA) was used to detect antibodies specific to Bovine Herpes Virus-1 (BoHV-1). The relationship of the categories under the variables was analyzed using a chisquare descriptive statistic. Logistic regression analyses were also used to assess potential predictive factors associated with the outcome variable. An overall animal level sero-prevalence of BoHV-1 antibodies were $77.6 \%$ (95\% $\mathrm{Cl}: 73.5-81.3 \%$ ) for the present study. In a random-effects of an adjusted logistic regression model, geographically the sero-prevalence of BoHV-1 exposure was higher for cattle's from East Gojam (Odds ratio $[\mathrm{OR}]=0.2 ; \mathrm{p}=0.002$ ) than in Awi zone (OR=1.4; $p=0.377)$ and West Gojam. The likelihood of disease occurrence for introduced cattle's were relatively higher $(O R=0.4 ; p=0.001)$ than homebred. Age of cattle's and parity status of heifers/cows were significantly associated with BoHV-1 infection $(\rho<0.001)$. The risk of infection was also positively correlated with the occurrence of respiratory problem $(\mathrm{OR}=2.2 ; \mathrm{P}=0.048)$. Thus, this result signifies that BoHV-1 is widely circulating among the indigenous zebus in the study areas. Given that there was no BoHV-1 vaccination delivery in the study area and in the country as a whole, control and prevention measures using marker vaccines were highly recommended.
\end{abstract}

Keywords: BoHV-1; Ethiopia; I-ELISA; Indigenous zebus; Sero-prevalence

\section{Introduction}

Infectious Bovine Rhinotracheitis (IBR) is a disease of domestic and wild cattle which is transmitted through semen; causing serious threat to reproductive health and productivity of cattle. The virus belongs to genus Varicellovirus in the subfamily Alphaherpesvirinae of the family Herpesviridae [1]. The disease caused by BoHV-1 can also cause infectious pustular vulvovaginitis (IPV), encephalomyelitis and mastitis. BoHV-1 affects respiratory, ocular, reproductive, alimentary, integumentary and central nervous systems besides causing neonatal infections [2]. Infections with this agent can also manifest as ocular, neonatal, gastro-intestinal, and neurologic disease as well as reproductive failure due to abortion and other genital symptoms IPV and Infectious Pustular Balanoposthitis (IPB) [3]. The disease is essentially a herd problem which occurs mostly in animals over 6 months of age. Transmission occurs normally by contact with infected animals, aerosol route and virus-contaminated semen from BoHV-1 infected bulls [4].

After an incubation period of 2-4 days, serous nasal discharge, salivation, fever, in appetence, and depression become evident. Within a few days the nasal and ocular discharges change to muco-purulent. Where natural mating is practiced, genital infection can lead to pustular vulvovaginitis or balanoposthitis. However, most infections run a very mild or subclinical course [5]. Secondary bacterial or viral agents may contribute to a multifactor disease complex resulting in severe respiratory disease of young animals ('shipping' or 'crowding fever'). However, uncomplicated cases of BoHV-1 which causes respiratory or genital disease last about 5-10 days.

Although, IBR is not a highly fatal disease, it can cause considerable economic losses due to abortion, loss of body condition, and milk yield, loss of new born calves, temporary failure of conception, insufficient feed conversion, secondary bacterial pneumonia and cost of treatment [6]. Abortion occurs as a consequence of infection of sero-negative cows by BoHV-1. The virus reaches the fetus by crossing the placental-blood barrier following systemic spread through viremia in animals afflicted by IBR [1]. It causes the death of the fetus before degeneration of the placenta occurs, hence there is a delayed expulsion resulting in in-utero autolysis of the fetus $[7,8]$ and frequent retention of fetal membranes. Abortions typically occur during 4-8 months of gestation within 15-64 days post infection regardless of the stage of pregnancy [2]. Other reproductive disorders associated with BoHV-1 include infertility with increased service per conception, metritis, and oophoritis [9].

Another important epidemiological feature of BoHV-1 is that infections usually produce latency. Despite the presence of colostral immunity, the virus maintains latency in trigeminal ganglion of the affected cattle and when they are stressed out due to various reasons, they shed the virus in the environment and become the source for infecting other susceptible cattle. It could be due to immune evasion mechanism and reactivation of the virus following exposure to stressors [10]. It has been suggested that late abortions occurring up 
to 100 days post infection might be the result of such reactivations [11].

The virus is distributed worldwide, except the BoHV-1-free countries [10]. Studies conducted in different countries across the world over the last 15 years reported varying sero-prevalence ranging from $35.9-77.5 \%$ in Europe and 37-60.8 \% in Latin America [12]. Recent reports from Sub-Saharan Africa on BoHV-1 sero-prevalence in cattle are scarce, but include $48.3 \%$ in Southern Zambia [13], 69\% in Ghana [14] and 74.5\% in Gauteng province of South Africa [15].

In Ethiopia, two preliminary surveys conducted in limited geographic areas in the mid-1970s and late 1980s demonstrated serological evidence of the presence of the virus in the country. Accordingly, the sero-prevalence of BoHV-1 was $41.8 \%$ in Harar and Sidamo provinces [16] and 67\% in Gobe and Ghibe in central Ethiopia [6]. Apart from the serological evidence in the two reports, the importance of the virus as the cause of reproductive disorder in milk shades of Central, Southern and Western Ethiopia has been investigated with a prevalence of $30.8 \%, 45.5 \%$ and $55.9 \%$ consecutively [17].

ELISA has been extensively used for the assessment of seroepidemiological investigation of BoHV-1 antibodies among cattle population in the various parts of the world $[18,19]$. Various intrinsic and extrinsic factors also influence the prevalence of infection among cattle population [20]. Therefore, the present study aimed to describe the sero-status and presumed risk factors of BoHV-1 among Indigenous zebus of extensively reared and semi-intensively managed cattle's in North western parts of Ethiopia.

\section{Study Method and Materials}

\section{Study area}

A cross-sectional study was conducted from November 2020June 2021 in indigenous breeds of extensively and semi-intensively grazing cattle's in North western parts of Ethiopia (i.e. East Gojam, West Gojam and Awi Zone). In East Gojam two districts were selected (Gozamen and D/Elias), West Gojam two district (Womberema and $\mathrm{B}$ /Zuria) and in Awi zone Jawi district alone was selected).

Gozamen is one of the district of East Gojam zone of Amhara regional states. It is found at a geographical location of $10^{\circ} 17^{\prime} 12^{\prime \prime} \mathrm{N}$ latitudes and $37^{\circ} 36^{\prime} 52^{\prime \prime} \mathrm{E}$ longitudes and at a distance of $305 \mathrm{~km}$ from Addis Ababa with an altitude ranging from 1200-3510 meter above sea level (masl). The average annual rainfall of the district was 1628 millimeter (mm) [21].

Debre Elias is also found in East Gojam zone of Amhara regional state, located $340 \mathrm{~km}$ away from Addis Ababa with an altitude of 2300 masl and having an average temperature of $27^{\circ} \mathrm{C}$. The area is predominantly rural and most residents live based on mixed agricultural system [22].

Womberma district is found in West Gojam zone, bordered on the south by river Abbay which separates it from Oromia regional state, on the west by Bure district, on the north and north east by Ankesha district and on the east by Guanga district. Its altitude ranges from 800 to 2212 masl. The area had a rainy season (June to September) and a longer dry season (October to May) with mean annual rain fall of $1115 \mathrm{~mm}$. The annual mean temperature for most parts of the district is $14-26^{\circ} \mathrm{C}$ [23].

Jawi district is located in Awi zone approximately $600 \mathrm{~km}$ Northwest of Addis Ababa. It lies within the geographical location of $36-37^{\circ} \mathrm{E}$ and $10^{\circ} 38^{\prime}$ to $11^{\circ} 30^{\prime} \mathrm{N}$. The district had an altitude ranging from 648 to 1300 masl. It has a climate which can be described as tropical with winter dry season. The agro-ecological area of the district had a warm and humid lowland zone around the area of the Belles River. The mean annual temperature varies between $25-40{ }^{\circ} \mathrm{C}$ with mean annual rain fall of $1569 \mathrm{~mm}$. The livestock population of the district comprises about 70,403 cattle, 6,549 sheep, 24,995 goats, 1,232 equines, 30,997 poultry and 7,520 bee hives [24].

\section{Study animals}

The study was conducted on indigenous zebus of extensively and semi-intensively reared cattle's including both sexes and all age groups except calves less than 6 months age. In Ethiopia, almost all studies regarding BoHV-1were targeted to dairy farms and breeding centers. No research was yet published on local breeds of extensively managed cattle's. This research might be the first to deal on local zebus of extensively grazing cattle's in the study area and hopefully in Ethiopia.

\section{Study design}

A cross-sectional study was conducted from November 2020 to June 2021. Various predictive risk factors (geographical variation, sex, age, origin, parity, abortion history, presence of ocular/nasal discharge, presence of respiratory problem and management) were included to observe their association with the possible outcome variable. Age in this study can be categorized as less than or equal to 2 years but greater than 6 months, 2 to 5 years and greater than 5 years. Origin will be either as a homebred or introduced. Parity will be categorized as primiparous (for cows/heifers having a single calf), pluriparous for cows having two or multiple calves and none (for heifers or cows that was not gave birth yet). Abortion history will be grouped as present or absent. Management of the cattle was categorized either as extensively reared or semi-intensively managed.

\section{Sampling technique}

Simple random sampling technique was used to select study animals from the study population. All essential epidemiological data for individual animal's were registered and recorded for presumed potential risk factors associated with BoHV-1 sero-positivity using data collection formats.

\section{Sample size determination}

Sample size determination was calculated based on $50 \%$ prevalence where there is no previous report at the study area using [25] formula.

$\mathrm{n}=\frac{\mathrm{Z}^{2^{*}} \operatorname{Pexp}(1-\mathrm{Pexp})}{\mathrm{d}^{2}}$

Where;

$\mathrm{n}=$ required sample size

Pexp $=$ expected prevalence

$\mathrm{d}=$ desired absolute precision

$\mathrm{Z}=1.96$ (constant)

With 5\% desired precision and 95\% confidence level was 
considered. Accordingly, the calculated sample size was 384 . But to increase the precision as the sampling areas were relatively wide, the sample size was increased with $15 \%$ to get a total sample size of 442 .

\section{Blood sampling}

Blood samples were collected using sterile vacutainer tubes of $10 \mathrm{ml}$ volume with no anticoagulant using $18 \mathrm{G}$ needle. The collected samples were settled overnight to separate the serum from the red blood cells. After a separate layer formation the serum part would be decanted into sterile cryovials of $1.8 \mathrm{ml}$ volume and transported on cold chain into national animal health diagnostic and investigation center (NAHDIC) and stored at $-20^{\circ} \mathrm{C}$ until laboratory work was conducted.

\section{Diagnostic procedures}

The serum based Indirect-ELISA was used for the detection of antibodies against BoHV-1. Briefly, allow all reagents to come into room temperature $\left(21^{\circ} \mathrm{C}+5^{\circ} \mathrm{C}\right)$ before use. Homogenize all reagents by inversion or vortex. Add $90 \mu \mathrm{l}$ of dilution buffer 2 to each microwell. Then add; $10 \mu \mathrm{l}$ of the negative control to wells A1 and B1, 10 $\mathrm{l}$ of positive control to wells $\mathrm{C} 1$ and $\mathrm{D} 1,10 \mu \mathrm{l}$ of each sample to be tested in the remaining wells. Incubate the plates for 45 minutes \pm 4 minutes at $37^{\circ} \mathrm{C}\left( \pm 3^{\circ} \mathrm{C}\right)$. Empty the wells. Wash each well 3 times with approximately $300 \mu \mathrm{l}$ of the wash solution. Avoid drying of the wells between washings. Prepare the conjugate $1 \mathrm{x}$ by diluting the concentrated conjugate $10 \mathrm{x}$ to $1 / 10$ in dilution buffer 3 . Add $100 \mu l$ of the conjugate $1 \mathrm{x}$ to each well. Incubate 30 minutes \pm 3 minutes at $37^{\circ} \mathrm{C}\left( \pm 3^{\circ} \mathrm{C}\right)$. Empty the wells. Wash each well 3 times again with approximately $300 \mu \mathrm{l}$ of the wash solution. Still avoid drying of the wells between washings. Add $100 \mu$ of the substrate solution (TMB) to each well. Incubate 15 minutes \pm 2 minutes at $21^{\circ} \mathrm{C}\left( \pm 5^{\circ} \mathrm{C}\right)$ in the dark. Lastly, add $100 \mu$ l of stop solution ( $0.5 \mathrm{M}$ sulfuric acid) to each well in order to halt the reaction. Then, read and record the OD values at $450 \mathrm{~nm}$ wave length.

$\%)$.

Interpretation: For each sample, calculate the $\mathrm{S} / \mathrm{P}$ percentage (S/P

Table 1: Over all sero-prevalence of BoHV-1 in the study areas.

\begin{tabular}{|c|c|c|}
\hline SN & No. of Positive (\%) & 95\% Confidence Interval (CI) \\
\hline 1 & $343 / 442(77.6)$ & $73.5-81.3$ \\
\hline
\end{tabular}

$\mathrm{S} / \mathrm{P} \%=\left(\left(\mathrm{OD}_{\text {sample }}-\mathrm{OD}_{\mathrm{NC}}\right) /\left(\mathrm{OD}_{\mathrm{PC}}-\mathrm{OD}_{\mathrm{NC}}\right)\right)^{*} 100$

For samples with an S/P \%:

- $\quad$ Less than $50 \%$ were considered negative.

- Greater than or equal to $50 \%$ and less than $60 \%$ were considered doubtful.

- Greater than or equal to $60 \%$ were considered positive.

\section{Data management and analysis}

The collected data were entered, cleaned, and coded into a Microsoft Excel Spreadsheet. The data was transported to Stata/ SE13.0 [26] software for analysis. Relationship of categorical variables with the outcome variable was first analyzed using a chi-square test. Then, the strength of the association in between various predictive factors was explored using Univariable logistic regression. For variables that showed co-linearity if any and variables with a p-value less than 0.25 upon a univariable logistic regression model, a further multivariable logistic regression analysis was built. P-value less than 0.05 were considered statistically significant for all statistical tools at a $95 \%$ CI.

\section{Results}

\section{Over all sero-status of the current study}

Of the total 442 samples tested for IBR indirect ELISA 343 (77.6\%; 95\% CI: 73.5-81.3) were sero positive for BoHV-1 antibody detection.

\section{Association of BoHV-1 exposure status and possible risk factors}

Based on environmental-related risk factors all predictive factors showed significance for the outcome variable. Variability's observed across different zones of the study revealed in East Gojam $(128 / 137=93.4 \%)$ where prevalence of the disease is significantly higher than West Gojam $(111 / 160=69.4 \%)$ and Awi Zone $(104 / 145=71.7 \%)$ with a $\left(\chi^{2}=28.8607 ; \mathrm{p}<0.001\right)$. Likewise, at district level, sero-prevalence of BoHV-1 antibodies was higher in Gozamen district $100 \%$ (46/46) and lowest in B/Zuria district 67\% (67/100) with a significant relationship $\left(\chi^{2}=31.4455 ; \mathrm{p}<0.001\right)$. Based on the origin of the study animal, introduced cattle have showed slightly higher prevalence $86.9 \%(113 / 130)$ than a homebred $73.7 \%$ (230/312) having

Table 2: Relationship of environmental related risk factors with the outcome variable.

\begin{tabular}{|c|c|c|c|c|c|}
\hline Variables & Category & Total no. of samples & Total no. of Positive (\%) & Chi-Square $\left(x^{2}\right)$ & p-value \\
\hline \multirow{3}{*}{ Zone } & East Gojam & 137 & $128(93.4)$ & \multirow{3}{*}{28.8607} & \multirow{3}{*}{$<0.001$} \\
\hline & West Gojam & 160 & $111(69.4)$ & & \\
\hline & Awi Zone & 145 & $104(71.7)$ & & \\
\hline \multirow{5}{*}{ District } & Gozamen & 46 & $46(100)$ & \multirow{5}{*}{31.4455} & \multirow{5}{*}{$<0.001$} \\
\hline & Debre Elias & 91 & $82(90.1)$ & & \\
\hline & Womberema & 60 & $44(73.3)$ & & \\
\hline & Jawi & 145 & $104(71.7)$ & & \\
\hline & B/Zuria & 100 & $67(67)$ & & \\
\hline \multirow{2}{*}{ Origin } & Purchased & 130 & $113(86.9)$ & \multirow{2}{*}{9.2061} & \multirow{2}{*}{0.002} \\
\hline & Homebred & 312 & $230(73.7)$ & & \\
\hline \multirow{2}{*}{ Management } & Extensive & 342 & $276(80.7)$ & \multirow{2}{*}{8.3574} & \multirow{2}{*}{0.004} \\
\hline & Semi-intensive & 100 & $67(67)$ & & \\
\hline
\end{tabular}


Table 3: Relationship of host related risk factors with dependent variable.

\begin{tabular}{|c|c|c|c|c|c|}
\hline Variables & Category & Total no. of samples & Total no. of Positive (\%) & $x^{2}$ & p-value \\
\hline \multirow{2}{*}{ Sex } & Male & 139 & $113(81.3)$ & \multirow{2}{*}{1.5911} & \multirow{2}{*}{0.207} \\
\hline & Female & 303 & $230(75.9)$ & & \\
\hline \multirow{3}{*}{ Age } & $<=2$ years & 96 & $38(39.6)$ & \multirow{3}{*}{105.7646} & \multirow{3}{*}{$<0.001$} \\
\hline & $2-5$ years & 148 & $123(83.1)$ & & \\
\hline & $>5$ years & 198 & $182(91.9)$ & & \\
\hline \multirow{3}{*}{ BCS } & Poor & 142 & $107(75.4)$ & \multirow{3}{*}{2.4728} & \multirow{3}{*}{0.29} \\
\hline & Medium & 159 & $130(81.8)$ & & \\
\hline & Good & 141 & $230(73.7)$ & & \\
\hline \multirow{3}{*}{ Parity } & Primiparous & 64 & $56(87.5)$ & \multirow{3}{*}{45.4147} & \multirow{3}{*}{$<0.001$} \\
\hline & Pluriparous & 113 & $103(91.5)$ & & \\
\hline & Non & 126 & $71(56.3)$ & & \\
\hline
\end{tabular}

Table 4: Relationship of clinically related risk factors with the outcome variable.

\begin{tabular}{|c|c|c|c|c|c|}
\hline Variables & Category & Total no. of samples & Total no. of Positive (\%) & $x^{2}$ & p-value \\
\hline \multirow{2}{*}{ Abortion history } & Aborted & 139 & $19(82.6)$ & \multirow{2}{*}{0.5596} & \multirow{2}{*}{0.454} \\
\hline & Non-aborted & 303 & $215(75.7)$ & & \\
\hline \multirow{2}{*}{ Ocular/Nasal discharge } & Present & 192 & $148(77.1)$ & \multirow{2}{*}{0.0525} & \multirow{2}{*}{0.819} \\
\hline & Absent & 250 & $195(78)$ & & \\
\hline \multirow{2}{*}{ Respiratory problem } & Present & 86 & $74(86)$ & \multirow{2}{*}{4.3808} & \multirow{2}{*}{0.036} \\
\hline & Absent & 356 & $269(75.6)$ & & \\
\hline
\end{tabular}

Table 5: Logistic regression analysis of the presumed environmental related risk factors in relation to BoHV-1 exposure among cattle's under the study.

\begin{tabular}{|c|c|c|c|c|c|}
\hline Predictive Variables & Categories & CRUDE OR $(95 \% \mathrm{CI})$ & p-value & ADJUSTED OR (95\% CI) & p-value \\
\hline \multirow{3}{*}{ Zone } & West Gojam & * & - & * & - \\
\hline & Awi Zone & $0.89(0.54-1.46)$ & 0.653 & $1.4(0.7-2.7)$ & 0.377 \\
\hline & East Gojam & $0.16(0.07-0.34)$ & $<0.001$ & $0.2(0.1-0.6)$ & 0.002 \\
\hline \multirow{2}{*}{ Origin } & Homebred & * & - & * & - \\
\hline & Introduced & $0.42(0.24-0.74)$ & 0.003 & $0.4(0.2-0.7)$ & 0.001 \\
\hline \multirow{2}{*}{ Management } & Semi-intensive & * & - & * & - \\
\hline & Extensive & $0.49(0.29-0.8)$ & 0.004 & $0.5(0.2-1.0)$ & 0.056 \\
\hline
\end{tabular}

a significant relationship $\left(\chi^{2}=9.2061 ; p=0.002\right)$. Extensively reared animals were more prone to the infection $80.7 \%$ (276/342) than those kept in semi-intensive $67 \%(67 / 100)$ which was also significantly related to the BoHV-1 antibody status $\left(\chi^{2}=8.3574 ; \mathrm{p}=0.004\right)$.

According to host related risk factors, age and parity showed significance for antibody detection of the disease $\left(\chi^{2}=105.7646\right.$; $\mathrm{p}<0.001)$ and $\left(\chi^{2}=45.4147 ; \mathrm{p}<0.001\right)$ respectively. However, the dependency of prevalence on sex and BCS was not significant $(\mathrm{p} \leq 0.05)$. The prevalence of adult animals ( $>5$ years) were relatively higher $91.9 \%(182 / 198)$ than animals aged $2-5$ years $83.1 \%(123 / 148)$ and young animals ( $<=2$ years) $39.6 \%$ (38/96). Similarly, the frequency of infection with BoHV-1 for pluriparous cows 91.5 (102/113) were slightly higher than primiparous heifers/cows $87.5 \%$ (56/64) and non parturated heifers and/or young calves $56.3 \%(71 / 126)$.

Animals with respiratory problems $86 \%$ (74/86) were relatively more affected with BoHV-1 than those hadn't the sign $75.6 \%$ (269/356). The variable is significantly associated with BoHV-1 antibody detection $\left(\chi^{2}=4.3808 ; \mathrm{p}=0.036\right)$. However, the rest variables (i.e. abortion history and ocular/nasal discharge) in this study were not significantly associated $(\mathrm{p}>0.05)$ with the disease exposure.

In random effect, multivariable logistic regression model, based on geographical location the sero-prevalence of BoHV-1 exposure was higher for cattle's from East Gojam $(\mathrm{OR}=0.2 ; \mathrm{p}=0.002)$ compared to cattle's at Awi zone (OR=1.4; $\mathrm{p}=0.377)$ and West Gojam. Similarly, the likelihood of being sero-positive for the antibody detection of BoHV-1 was higher for introduced cattle's $(\mathrm{OR}=0.2 ; \mathrm{p}=0.001)$ than homebred animals. However, no significant association was noted for BoHV -1 antibody positivity with respect to management $(p>0.05)$ at an adjusted logistic regression model as shown in Table 5.

Animals sampled from age of greater than 5 years (old cattle's) had significantly higher odds of being sero-positive (Adjusted Odd Ratio $[\mathrm{AOR}]=0.08 ; \mathrm{p}<0.001)$ as compared to their counterparts. The rest explanatory variables (Sex, BCS and Parity) were not statistically associated with BoHV-1 sero-status (Table 6). 
Table 6: Logistic regression analysis of the presumed host related risk factors with BoHV-1 exposure among cattle's in the study area.

\begin{tabular}{|c|c|c|c|c|c|}
\hline Predictive Variables & Categories & CRUDE OR $(95 \% \mathrm{CI})$ & $p$-value & ADJUSTED OR (95\% Cl) & p-value \\
\hline \multirow{2}{*}{ Sex } & Male & * & - & * & - \\
\hline & Female & $1.4(0.8-2.3)$ & 0.208 & $1(0.4-2.5)$ & 0.994 \\
\hline \multirow{3}{*}{ Age } & $<=2$ years & * & - & - & - \\
\hline & $2-5$ years & $0.13(0.07-0.24)$ & $<0.001$ & $0.2(0.1-0.3)$ & $<0.001$ \\
\hline & $>5$ years & $0.06(0.03-0.11)$ & $<0.001$ & $0.08(0.04-0.18)$ & $<0.001$ \\
\hline \multirow{3}{*}{ BSC } & Poor & * & - & - & - \\
\hline & Medium & $0.7(0.4-1.2)$ & 0.176 & $0.8(0.4-1.6)$ & 0.549 \\
\hline & Good & $1(0.6-1.7)$ & 0.973 & $0.8(0.4-1.6)$ & 0.543 \\
\hline \multirow{3}{*}{ Parity } & Primiparous & * & - & - & - \\
\hline & Pluriparous & $0.7(0.3-1.8)$ & 0.442 & $0.9(0.3-2.7)$ & 0.899 \\
\hline & Non & $5.4(2.4-12.3)$ & $<0.001$ & $1.9(0.7-4.7)$ & 0.185 \\
\hline
\end{tabular}

Table 7: Logistic regression analysis of the presumed clinically related risk factors with BoHV-1 exposure among cattle's under the study.

\begin{tabular}{|c|c|c|c|c|}
\hline Predictive Variables & Categories & CRUDE OR (95\% CI) & p-value & ADJUSTED OR (95\% CI) \\
\hline \multirow{2}{*}{ Abortion history } & Aborted & $*$ & - & - \\
\hline \multirow{2}{*}{ Ocular/Nasal discharge } & Non aborted & $1.5(0.5-4.6)$ & - & - \\
\cline { 2 - 5 } & Present & $*$ & 0.457 & - \\
\hline \multirow{2}{*}{ Respiratory problem } & Absent & $1(0.6-1.5)$ & - & - \\
\hline & Present & $*$ & - \\
\hline
\end{tabular}

Ocular/Nasal
discharge

Figure 1: Relationship of BoHV-1 sero-status with cattle's having clinical disorders.

Cattle's that showed respiratory problem had more likely to be positive for BoHV-1 antibody detection ( $\mathrm{AOR}=2.2$; $\mathrm{p}=0.048$ ) than cattle's which cannot manifest the sign. Other presumed risk factors (abortion status and ocular/nasal discharge) were not statistically significant for univariable logistic regression analysis and indeed for multivariable (Table 7).

Proportions of clinical disorders were higher in sero-positive cattle's as compared to sero-negative ones in the study area as illustrated in Figure 1.

\section{Discussion}

BoHV-1 is involved in the respiratory disease complex. Clinical signs of BoHV-1 include symptoms of inflammatory processes in both respiratory and genital organs, and abortion [10]. This study was designed to determine the Sero status and presumed risk factors assessment for Bovineherpesvirus-1 in indigenous breeds of extensively and semi-intensively grazing cattle's. In the current study, BoHV-1 antibody status for extensively and semi-intensively reared cattle's were $80.7 \%$ and $67 \%$ respectively, with a total prevalence of $77.6 \%$ (95\% CI: 73.5-81.3). This result indicates that, the devastating effect of the disease was not only confined to improved dairy cattle alone, but also established and distributed to local zebus with high rate in the north western part of Ethiopia. Moreover, previous reports of the infection exposure in local zebu cattle from central Ethiopia (67\%) [6] affirm the endemic nature of the disease in the country.

The sero-prevalence of BoHV-1 found in this study was higher than the findings of [27] 10.39\% in India, [28] 19.5\% in Turkey and [29] $24.19 \%$ in Algeria. Similar studies in other countries indicated that sero-prevalence of the disease was high (64.4\%) in north eastern Mexico [30], 66.12\% in India [31], 60.84\% in India [32], and $93.75 \%$ in Egypt from cattle imported from Sudan [33], and 63.54\% in southern India [34]. In Ethiopia, relatively high prevalence was reported with prevalence of $67 \%$ in Gobe and Ghibe [6], 41.8\% in Harar and Sidamo provinces [16] and 41.0\% in Addis Ababa, central and southern including southwestern parts of Ethiopia [17]. This indicates that BoHV-1 sero-prevalence was higher and ranged from $10.39 \%$ to $93.75 \%$ in various parts of the world. The difference in the sero-prevalence across countries may be attributed to variations in geographical locations, year of study, area/district selected for sample collection, variation in management such as housing, feeding, semen quality during breeding, and health care program used by these countries.

Sero-prevalence of BoHV-1 in the literature are in the range of 7.5-70.89\% [30, 35and 36]. This indicates a wide geographical distribution of the disease and its level of presence in various countries. The prevalence of the disease in neighboring provinces of Turkey also ranges from 0 to $79.7 \%$ [37]. Such differences could be 
the results of localized outbreaks of the disease in some of the study herds, but could also be due to chance because of the small sample size from the farms and also small number of herds sampled per conurbation and type of test employed [17].

In the present study, the disease sero-status was relatively lower than the reports of [38] who found $90 \%$ prevalence in humid tropics of Mexico and 93.75\% in Egypt from cattle imported from Sudan [33]. Yet, no vaccination for IBR in Ethiopia has been delivered. The wide distribution and high sero-prevalence of BoHV-1 in this study had been a strong indicator that the virus was circulating in indigenous cattle's in the areas. Thus, there might be a large pool of latently infected cattle that could potentially serve as a source of infection for other animals, as infected cattle are considered to be infected for life [1]. Therefore, control and prevention of the disease were indicated through the use of vaccinations, preferably using marker vaccines until the prevalence of the disease would be decreased to the level where test and culling could be considered as an alternative [39].

Based on geographical location, the study areas were significantly associated $(\mathrm{P}<0.001)$ with sero-prevalence of BoHV-1 infection. This heterogeneity may be related to the density of cattle's in each rural district; differences in prevalence between districts and by factors such as herd size, disease control measures, type of breeding and age of the animal [40].

The sex wise prevalence of BoHV-1 in this study was statistically not significant $(\mathrm{P}>0.05)$. However, relatively high prevalence was observed in males $(81.3 \%)$ than females $(75.9 \%)$. This result was in agreement with [41] who reported a prevalence of (48\%) for males compared to $(29.35 \%)$ in females. Contrary to the present and the observations of others, various authors have observed higher prevalence rate in females than males. Of which (19.02\%) females than (16.22\%) males in Uttarakhand [42]; (12.35\%) females than (5.80\%) by $[43,35]$ also reported $(67.92 \%)$ female than $(33.33 \%)$ male. The probable reason for the high prevalence of sero-positivity in males than females in this study might be behavior of male animals as they behave to lick the discharges, which is the good source of infection from female genitalia and also the exposure with more number of females and that during the estrous or post abortion period or post parturition estrous when there are more chances of virus shading in discharges.

Age was frequently reported as the major risk factor for BoHV-1 sero-positivity where, as age increases, detection of antibody for the disease is also increases. Cattle's of any age are susceptible to BoHV-1 but the disease occurs most commonly in animals over 6 months old, probably because of their greater exposure to the infective agent and loss of maternal immunity. In this study also animals greater than 5 years were more prevalent for the disease antibody detection than other age groups with statistical significance of $(\mathrm{p}<0.001)$. Indeed, this study was in line with the reports of [40, 44-47] who reported higher sero-prevalence of the disease in old animals. The possible reason for this might be increased susceptibility of animals with age or repeated subclinical infection with the virus that boost to keep the antibody titer higher enough to be detected positive or decrease in immunity and increase in stress, which may lead to reactivation of latent virus [48].
Significant differences for sero-prevalence of BoHV-1 in this study were observed between animals introduced (86.9\%) and homebred (73.7\%) with ( $\mathrm{p}=0.002)$. This might be due to respiratory form of the disease is associated with frequent introduction of cattle from various parts of the country and intensive management practices of cattle [49]. However, the result was in contrary with the finding of [30].

Sero-positivity for the disease were proportionally increases as the number of calving increases based on parity of heifers and/ or cows (i.e. female cattle's with no parity (56.3\%), primiparous heifers/cows (87.5\%) and pluriparious cows (91.5\%) with statistical significance of $(p<0.001))$. This finding was in consistent with the reports of [17] who found (33.5\%) prevalence for multiparous and (14.9\%) for primiparous dairy cattle being higher in multiparous with above two fold risk for multiparous than primiparous. This might be due to the repeated exposure to breeding where by the infection being able to occur from the bull or AI service.

Abortion occurring mainly at the late stage of gestation due to BoHV-1 infection causes the most economic losses in dairy cattle. This loss is recognized by most of the countries and is using vaccination against IBR; eradication of the disease is possible [50]. Although in the current study abortion was not significantly associated with the outcome variable, the prevalence of cattle's experienced abortion were relatively higher (82.6\%) than non aborted cows/heifers (75.7\%) which was in line with the reports of [51] who found, 79.69\% abortion cases for IBR in India. An abortion of 100\% sero-positive for IBR was also reported in Southern India [34]. This indicates that IBR has contributed to the occurrence of reproductive disorders.

Regarding management, higher prevalence was obtained in extensively reared zebus (80.5\%) than semi-intensively managed cattle's $(67 \%)$ in this study. The possible reason for higher prevalence in extensively reared cattle's could be the practice of natural bull mating with bulls of unknown health status that causes the rapid spread of the disease [52] and high contact rate with unknown herds of the neighbors $[40,53]$ reported that herds with high stock density are associated with high odds for BoHV-1 infection.

In conclusion, most of presumed risk factors in this study were significantly associated with the dependent variable except BCS, sex, Abortion status and presence or absence of ocular/nasal discharges. The fact that animals were not vaccinated and that all age-groups had high sero-prevalence indicates that BoHV-1 is naturally circulating in the population. The distribution of virus and risk factors identification are important in order to establish measures for the epidemiological prevention and control programs against this economically important disease to minimize its incidence.

\section{Conclusion and Recommendations}

The present study clearly showed the wide spread of BoHV-1 in non-vaccinated animals of all age-groups, which might be thought that the virus is naturally and latently existing in local zebus of extensively and semi-intensively reared cattle's in north western parts of Ethiopia. As the disease affect the reproductive function of the animals, thus may cause a significant economic losses on the sector. The study findings warrant that a suitable action plan should be implemented to control the spread of virus in the study area in particular and in the country in general. Based on the present findings, 
we recommend a wisely usage of marker vaccine which enables to differentiate the wild infection upon serological assay, to prevent and control infection from the population and further spread. Planned bio-security measures are also needed to control the epidemiological risk of infection due to the presence of BoHV-1 latent carriers.

\section{References}

1. Muylkens B, Thiry J, Kirten P, Schynts F, Thiry E. Bovine herpesvirus 1 infection and infectious bovine rhinotracheitis. Vet Res. 2007; 38: 181-209.

2. Gibbs EPJ, Rweyemamu MM. Bovine herpesviruses. Part I. Bovine herpesvirus 1. Bulletin. 1977; 47: 317-343

3. Gould S, Cooper V, Reichardt N, O'Connor A. An evaluation of the prevalence of bovine herpesvirus 1 abortions based on diagnostic submissions to five U.S. based veterinary diagnostic laboratories. J Vet Diagn Invest. 2013; 25 : 243-247.

4. Fulton R, d'Offay J, Eberle R. Bovine herpesvirus-Comparison and differentiation of vaccine and field strains based on genomic sequence variation. Vaccine. 2013; 31: 1471-1419.

5. Van Oirschot JT, Straver PJ, Van Lieshout JAH, Quak J, Westenbrink F, Van Exsel ACA. A subclinical infection of bulls with bovine herpes virus type 1 at an artificial insemination centre. Vet Rec. 1993; 132: 32-35.

6. Bekele T, Cecchini G, Kassali OB, Scholtens RG, Mukassa-Mugurewa E. Infectious bovine rhinotracheitis/infectious pustular vulvovaginitis (IBR/IPV) in cattle in central Ethiopia. Bull. Anim. Health Prod. Afr. 1989; 37: 97-98.

7. Molello JA, Chow TL, Owen N, Jensen R. Placental pathology. V. Placental lesions of cattle experimentally infected with infectious bovine rhinotracheitis virus. Am J Vet Res. 1966; 27: 907-915

8. Kendrick JW, Straub OC. Infectious bovine rhinotracheits-infectious bovine vulvovaginitis. Am J Vet Res. 1967; 28: 1269-1282.

9. Graham DA. Bovine herpesvirus-1 (BoHV-1) in cattle-a review with emphasis on reproductive impacts and the emergence of infection in Ireland and the United Kingdom. Ir Vet J. 2013; 66: 15.

10. OIE. Terrestrial manual chapter 2.4.13. Infectious Bovine Rhinotracheitis/ InfectiousPustular Vulvovaginitis. 2010.

11. Jones $\mathrm{C}$, Chowdhury S. A review of the biology of bovine herpesvirus type 1 (BHV-1), its role as a cofactor in the bovine respiratory disease complex and development of improved vaccines. Anim. Health Res. Rev. 2008; 8: 187-205.

12. Raaperi K, Orro T, Viltrop A. Epidemiology and control of bovine herpesvirusinfection in Europe. Vet J. 2014; 201: 249-256.

13. Mweene AS, Fukushi H, Pandey GS, Syakalima M, Simuunza M, Malamo M et al. The prevalence of bovine herpesvirus-1 in traditional cattle in Southern Province. Zambia Rev Sci Tech Off Int Epiz. 2003; 22: 873-877.

14. Adu-Addai B, Koney EB, Addo P, Kaneene J, Mackenzie C, Agnew DW. Importance of infectious bovine reproductive diseases: an example from Ghana. Vet Rec. 2012; 171: 47

15. Njiro SM, Kidanemariam AG, Tsotetsi AM, Katsande TC, Mnisi M, Lubisi BA et al. A study of some infectious causes of reproductive disorders in cattle owned by resource-poor farmers in Gauteng Province, South Africa. J S Afr Vet Assoc. 2011; 82: 213-218.

16. Lefevre PC. Report on infections bovine rhinotracheitis in Ethiopia. Preliminary serological survey. Rev Elev Méd Vét Pays Trop. 1975; 28: 115-124.

17. Sibhat B, Ayelet G, Skjerve E, Zewdu E, Asmare K. Bovine herpesvirus-1 in three major milk sheds of Ethiopia: Serostatus and association with reproductive disorders in dairy cattle. Prev Vet Med. 2018; 150: 126-132.

18. Iscan UT, Duman R. Bovine herpesvirus type-1 (BHV-1) prevalence in dairy cattle. J Anim Vet Adv. 2011; 10: 1523-1525.

19. Roshtkhari, F., Mohammadi, G. and Mayameei, A. Serological evaluation of relationship between viral pathogens (BHV-1, BVDV, BRSV, PI-3V, and Adeno3) and dairy calf pneumonia by indirect ELISA. Trop. Anim. Health
Prod. 2012; 44: 1105-1110.

20. Keneisezo K, Neithono K, Keneisevono K, Limasenla P, Kevisenuo E. Sathiyabama K. Bovine herpes virus $-1(\mathrm{BoHV}-1)$ in cattle: A review with emphasis on epidemiological parameters influencing the prevalence of bovine herpes virus -1 in cattle in India. J Entomol Zool Stud. 2019; 7: 284290.

21. GWARDO. Gozamin District Agricultural and Rural Development Office Annual Report. Debre Markos, Ethiopia. 2014.

22. Tesfa Yohnnes, T. and Kloos, H. Intestinal parasitism. In: Zein A.Z and Helmut Kloos (Eds).The ecology of health \& disease in Ethiopia. Addis Ababa: Ministry of Health. 1998; 214-230.

23. OWWARD. Office of Wemberma Wereda agricultural and rural development wereda profile document. 2004

24. AAZARD. Awi Administrative Zone Agricultural and Rural Development Annual report. 2008.

25. Thrusfield M. Veterinary Epidemiology, $3^{\text {rd }}$ edition. Blackwell Publishing Ames, lowa, USA. 2007.

26. StataCorp. Statistical software, 2013 version 13 stata Corporation. Collage StationTexas, USA. 2013

27. Nandi S, Kumar M, Manohar M, Chauhan R. Bovine herpesvirus infections in cattle. Anim Health Res Rev. 2009; 10: 85-98.

28. Tan MT, Yildirim Y, Erol N, Güngör AB. Seroprevalence of Bovine Herpes Virus type 1 (BHV-1) and Bovine Leukemia Virus (BLV) in selected dairy cattle herds in Aydın province, Turkey. Turkish Journal of Veterinary and Animal Sciences. 2006; 30: 353-357.

29. Kaddour A, Bouyoucef A, Fernandez G, Prieto A, Geda F, Moula N. Bovine herpesvirus 1 in the northeast of Algiers, Algeria: Seroprevalence and associated risk factors in dairy herd. Journal of Advanced Veterinary and Animal Research. 2019; 6: 60-65.

30. Segura-Correa JC, Zapata-Campos CC, Jasso-Obregón JO, MartinezBurnes J, López-Zavala R. Seroprevalence and risk factors associated with bovine herpesvirus 1 and bovine viral diarrhea virus in North-Eastern Mexico. Open Vet J. 2016; 6: 143-149.

31. Trangadia B, Rana SK, Mukherjee F, Srinivasan VA. Prevalence of brucellosis and infectious bovine rhinotracheitis in organized dairy farms in India. Trop. Anim. Health Prod. 2010; 42: 203-207.

32. Trangadia BJ, Rana SK, Nagmani K, Srinivasan VA. Serological investigation of bovine brucellosis, Johne's disease and infectious bovine rhinotracheitis in two states of India. Indian J Adv Vet Res. 2012; 2: 38-41.

33. Hussein S, Hekal A, Al-gaabary MH, El-sayed MM, Sobhy HM, Abdul A, et al Seroprevalence of some Infectious transboundry diseases in cattle imported from Sudan to Egypt. 2019; 92-99

34. Krishnamoorthy P, Patil S. S, Shome R, Rahman H. Sero-epidemiology of infectious bovine rhinotracheitis and brucellosis in organised dairy farms in Southern India. Indian J Anim Sci. 2015; 85: 695-700.

35. Saravanajayam M, Kumanan K, Balasubramaniam A. Seroepidemiology of infectious bovine rhinotracheitis infection in unvaccinated cattle. Vet World 2015; 8: 1416-1419.

36. Yousef MR, Mahmoud MA, Ali SM, Al-Blowi MH. Seroprevalence of some bovine viral respiratory diseases among non-vaccinated in Saudi Arabia. Vet World. 2013; 6: 1-4.

37. Aslan ME, Azkur AK, Gazyagci S. Epidemiology and genetic characterization of BVDV, BHV-1, BHV-4, BHV-5 and Brucella spp. infections in cattle in Turkey. J Vet Med Sci. 2015; 77: 1371-1377.

38. Córdova-Izquierdo A, Córdova-Jiménez C, Saltijeral-Oaxaca J, Ruiz-Lang C, Cortes-Suarez S, Guerra-Liera J. Seroprevalencia de enfermedades causantes de aborto bovino en el trópico húmedo Mexicano. Rev Vet. 2007; 18: $139-142$

39. Constable PD, Hinchcliff KW, Done SH, Grünberg W. Bovine tuberculosis. Veterinary Medicine: A Textbook of the Diseases of Cattle, Horses, Sheep, 
Pigs, and Goats, $11^{\text {th }}$ edition. Elsevier, St. Louis, Missouri. 2017; 952-961.

40. McDermott JJ, Kadohira M, O'Callaghan CJ, Shoukri MM. A comparison of different models for assessing variation in the seroprevalence of infectious bovine rhinotracheitis by farm, area and district in Kenya. Prev Vet Med. 1997; 32: 219-234.

41. Verma AK, Kumar A, Sahzad Reddy NCP, Shende AN. Seroprevalence of infectious bovine rhinotracheitis in dairy animals with reproductive disorders in Uttar Pradesh. India Pak J Biol Sci. 2014; 17: 720-724.

42. Thakur V, Kumar M, Nandi S, Rathish RL. Detection of bovine herpes virus1antibodies in bovines in three districts of Uttarakhand by competitive ELISA Haryana Vet. 2015; 54: 168-170.

43. Jain V, Parihar AK, Upadhayay AK, Kumar M. Sero-epidemiology of IBR among bovines of Garwal region. Indian Vet. J. 2006; 83: 340-342.

44. De Quevedo JM, Aguilar SA, Correa GP, Berruecos JM. Algunos aspectos epizotiológicos de la rinotraqueitis infecciosa bovina. Tec. Pecu. Mex. 1978; 34: 61-68.

45. Orjuela J, Navarrete M, Betancourt A, Roqueme L, Cortez E, Morrison RB. Salud y productividad en bovinos de la costa norte de Colombia. World Anim Rev. 1991; 69: 7-14

46. Hage JJ, Schukken YH, Digkstra TH, Barkema HW, Van Valkengoed PHR, Wentink GH. Milk production and reproduction during a subclinical bovine herpesvirus infection on a dairy farm. Prev Vet Med. 1998; 34: 97-106.

47. Solis-Calderon JJ, Segura-Correa VM, Segura-Correa JC, Alvarado-Islas A Seroprevalence and risk factors for infectious bovine rhinotracheitis in beef cattle herds of Yucatan, Mexico. Prev Vet Med. 2003; 57: 199-208.
48. Singh A, Sinha BK. Seroprevalence of Infectious Bovine Rhinotracheitis (IBR) In Cattle In Bihar. Indian J. Comp. Microbiol. Immunol. Infect. Dis. 2006; 27: 107-108.

49. Ampe B, Duchateau L, Speybroeck N, Berkvens D, Dupont A, Kerkhofs $P$. Assessment of the long-term effect of vaccination on transmission of infectious bovine rhino tracheitis virus in cattle herds hyperimmunized with glycoprotein E-deleted marker vaccine. Am J Vet Res. 2012; 73: 1787-1793.

50. Singh R, Verma AK, Sharma B, Yadav SK. Detection of Bovine Herpesvirus-I (BHV-I) infection in cattle by antigen detection ELISA and multiplex PCR. Adv Anim Vet Sci. 2013; 1: 12-16.

51. Kathiriya J, Sindhi S, Mathapati B, Bhedi K. Seroprevalence of Infectious Bovine Rhinotracheitis (IBR) in Dairy Animals with Reproductive Disorders in Saurashtra of Gujarat, India. 2018.

52. Romero-Salas D, Ahuja-Aguirre C, Montiel-Palacios F, Garcia-Vazquez Z, Cruz-Romero A, Aguilar-Dominguez M. Seroprevalence and risk factors associated with infectious bovine rhinotracheitis in unvaccinated cattle in Southern Veracruz, Mexico. Afr J Microbiol Res. 2013; 17: 1716-1722.

53. Van Wuijkhuise L, Bosch J, Franken P, Hage J, Verhoeff J, Zimmer G. The prevalence of IBR in the Netherlands. Proceedings of the $7^{\text {th }}$ International Symposium on Veterinary Epidemiology and Economics, Nairobi, Kenya. 1998. 